https://doi.org/10.5937/bizinfo2002033D

\title{
Authentic leadership: women leaders in Serbia
}

\section{Autentično liderstvo: žene lideri u Srbiji}

\author{
Sandra Dramićanin $^{\text {a* }}$, Snežana Mihajlov ${ }^{\mathrm{b}}$, Nebojša Pavlović ${ }^{\mathrm{a}}$ \\ ${ }^{a}$ University of Kragujevac, Faculty of Hotel Management and Tourism in Vrnjačka Banja, \\ Serbia \\ ${ }^{\mathrm{b}}$ Academy of Professional Studies South Serbia, Department of Business Studies Blace, Serbia
}

\begin{abstract}
Authentic leaders are people who are aware of themselves and own capabilities, who respect other people's opinions, perspectives and attitudes (about business and them as leaders), who are guided by high moral principles and practice transparency in business and communication with other employees. The aim of this research is to show are the women leaders in Serbia belong to the authentic type of leader and which of the characteristics of the authentic leader is the most common among them. In the research 113 women leaders from various activities from the territory of the Republic of Serbia participated. Of the total number of respondents, 31 results show an authentic leadership style, while only 3 results show a strong authentic style. Self-awareness is a dimension that stands out in relation to the other three and characterizes the largest number of women leaders. Further analysis showed that the greatest leadership potential in terms of authentic leadership has women who deal with services, have between 36-45 years and 10-15 years of work experience in the business in which they are engaged and have Bachelor's degree. The society in Serbia is such that it prefers male leaders, the goal of this research is to show that women are excellent leaders based on their characteristics and to have the predisposition to become great authentic leaders.
\end{abstract}

Keywords: women's leadership, authentic leadership, self-awareness, internalized moral perspective, balanced processing, relational transparency

Sažetak: Autentičani lideri predstavljaju osobe koje su svesne sebe i svojih mogućnosti, dok istovremeno uvažavaju tuđe mišljenje, perspektivu rešavanja problema i stavove (vezano za poslovanje, a $i$ njih kao lidere), vode se visokim moralnim načelima $i$ praktikuju transparentnost u svakodnevnom poslovanju i komunikaciji sa ostalim zaposlenima. Cilj ovog istraživanja je da pokaže da li žene lideri u Srbiji pripadaju autentičnom tipu lidera i koja od karakteristika autentičnog lidera je najzastupljenija kod njih. U istraživanju je učestvovalo

*Corresponding author.

E-mail address: sandradramicanin@ @otmail.com

This is an open access paper under the license cc) (i) () 
113 žena lidera iz različitih delatnosti sa teritorije Republike Srbije. Od ukupnog broja ispitanica, kod 31 rezultati pokazuju autentičan stil vođenja, dok samo kod 3 rezultati prikazuju snažan autentičan stil. Samosvest je dimenzija koja se izdvaja u odnosu na ostale tri $i$ karakteriše najveći broj žena lidera. Daljom analizom, uočeno je da najveći liderski potencijal u smislu autentičnog liderstva imaju žene koje se bave uslugama, imaju između 36-45 godina i 10-15 godina radnog iskustva u delatnosti kojom se bave i završenim fakultetom. S obzirom da je društvo u Srbiji takvo da preferira muškarce lidere, cilj je da se prikaže da su žene na osnovu karakteristika odlični lideri i da poseduju predispozicije da postanu i sjajni autentični lideri.

Ključne reči: žensko liderstvo, autentično liderstvo, samosvest, internalizovani moral, balansirano procesuiranje informacija, transparentnost

\section{Introduction}

Authentic leadership is the latest style of leadership and it has been the subject of research only a few decades back. Given the modern way of doing business, authentic leaders are necessary in organizations in order for them to stay in the market, while supporting employees and directing them to freely express their views, work and meet goals. While organizations and their members are grappling with conflicting social and economic pressures, authenticity has become the gold standard for leadership (Ibarra, 2015). Authentic leaders lead employees in such a way that they do not copy anyone's way of managing, but try to be their own and consistent with them at all times in the business. Such leaders are independent in work, do not work according to other people's wishes and needs, do not make false promises and they are characterized by dignified behavior in every situation. Today, authentic leaders present themselves as the best leaders. They create a culture of organization and a work climate in which creativity, innovation, focus, commitment, articulation and inspiration are most prevalent. Authentic leadership is the core for building advanced leadership theory and related concepts: transactional, transformational, charismatic, command, collider, ethical, emotional, global, team, visionary leadership, and other leadership styles (Avolio \& Gardner, 2005).

Authentic leaders are transparent in their intentions and at the same time possess a flawless connection between the values they stand for, actions and behaviors (Luthans $\&$ Avolio, 2003). The mission and goals of the organization in which they work are always ahead of their own goals, because they work and lead employees in the direction of accomplishing tasks, not for money or power, and they are guided by the heart, in cooperation with the mind (George, 2011).

The concept and generally accepted framework of authentic leadership is a multidimensional construct with four interrelated dimensions: self-awareness, internalized moral perspective, balanced information processing, and transparency (Walumbwa et al., 2008). Authentic leaders are aware of their values, quality and beliefs; also they are confident, trustworthy, reliable and honest. They focus on building relationships and strengths of employees by expanding their aspects and engaging them so that a positive organizational context is created (Dramićanin, 2019).

In relation to authentic leadership, the gender of authentic leaders remained unexplored throughout the year. In their research, the authors did not make a 
distinction between female and male authentic leaders (Liu et al., 2015). There are very few papers that research authentic female leadership and female leadership in general. However, the contribution of women in modern business has been increasing in recent years, so they are gaining important roles in organizations and their way of leading is beginning to be studied.

Women are recognized as leaders of change in more and more areas in Serbia. The knowledge, abilities and creativity that women leaders possess represent a great resource of Serbia. Women leaders in Serbia have a clear vision, make detailed and concrete plans, they are ready to invest in their careers, they are aware that they need to invest a lot of work, effort, be persistent and not give up. Following the wishes and goals, they start jobs, ideas, new projects, develop them and inspire their employees, thus making them follow them, building opportunities for their own, but also for the professional development of their subordinates. In this paper, women leaders from Serbia represented the respondents, in order to determine which of them has the characteristics of an authentic leader and to what extent these characteristics are expressed. Research was also conducted in relation to the demographic characteristics of the respondents.

\section{Authentic leadership}

Leadership theories imply a certain leadership style, which encompasses a series of harmonized activities and procedures that make up a certain, characteristic way of leading a group. Different leaders, in accordance with their personality, education, but also the nature and tasks of the group they lead, apply different leadership styles, so that each of them has a special and dominant way of leadership. The latest leadership style has captured the attention of researchers, and is based on originality and a real leader (Northouse, 2018). An authentic leader is characterized by positive psychic abilities, a positive ethical climate, nurturing an inner moral perspective, a balanced approach to decision-making, quality work with followers, and continuous selfdevelopment (Ford \& Harding, 2011).

Authentic leadership has attracted researchers' attention due to its positive influence on employees and organizational-goal achievements (Walumbwa et al., 2014). Authentic leadership is a model of leader behavior that promotes positive psychological capacities and a positive ethical climate, to foster greater selfawareness, an internalized moral perspective, balanced processing of information, and relative transparency on the part of leaders working with followers, fostering positive self -development (Walumbwa et al., 2008). Self-awareness is conceptualized as an understanding of how one makes sense of the world and how this process influences one's self-concept, strengths and weaknesses (Avolio \& Gardner, 2005). Internalized moral perspective is self-regulation guided by internal moral standards (Gardner et al., 2011). Balanced processing of information is described as the objective analysis of relevant information before decision-making (Walumbwa et al., 2010). Relational transparency is the presentation of one's authentic, true self to others (Avolio, 2011). Authentic leadership is a relative leadership style purported to promote healthy work environments that influence staff performance and organizational outcomes (Alilyyani et al., 2018). The focus of an authentic leader is on empowering and supporting 
employees. It is reflected in the fact that an authentic leader is a significant link and the maximum contribution to sustainable business. The essence of authentic leadership lies within its relational nature. The ultimate purpose of authentic leadership is to create authentic followership (Leroy et al., 2015). Authenticity is not a property which can be given to another individual (Algera \& Lips-Wiersma, 2012). Guided by personal moral standards, an authentic leader positively influences, provides support and encourages employees to express opposing opinions and views. Employees' experiences of authentic organizational behavior depend on transparency, trustfulness and consistency in leadership approaches (Shen \& Kim, 2012). Dedicated to their work, due to the support and empowerment by their leader, employees give their maximum (Iqbal et al., 2020). Through his work, the leader plays an important role in creating a high business performance; because leader always has a convincing vision and actions are always directed towards the interests of the organization (Ilies et al., 2005).

\section{Women and authentic leadership}

Existing literature on the topic of authentic leadership describes leaders as heroes. In this way, individualistic governance is encouraged, rather than recognizing and rewarding relevant aspects of leadership. At the same time, this way of perceiving authentic leadership sacrifices women and the way in which they fight to establish authentic leadership among employees. Also, there are gender stereotypes and assumptions about what women should do and what men should do (Heilman, 2012). Authentic leadership can manifest in two forms: enabling and controlling authentic leadership (Qiu et al., 2019). Enabling authentic leadership with generous valuecontent manifested through humility, integrity, accountability, security, and vulnerability (Udani \& Lorenzo-Molo, 2013). Controlling authentic leadership is value-free and often prioritizing self-expression, even at the expense of others (Zander, 2013). These two forms reflect feminine and masculine viewpoints (Ibarra, 2015).

Earlier theories of authentic leadership have shown that women do not belong to this style unlike men. However, Liu et al. (2015) proved the opposite and concluded that women are especially important leaders in crisis situations in order to solve problems. Authentic women leaders in such situations tend to be less aggressive than authentic men's leaders (Bligh, Kohles, 2008).

Nowadays, authentic leadership is quite challenging for women leaders for three reasons: different treatment of women and men, lack of gender neutrality and emphasis exclusively on the authentic leader instead of the leader in relation to employees (Hopkins \& O'Neil, 2015). Authentic leadership helps women discover and pursue purpose, goals and is a powerful motivator and helps women leaders inspire others. Authentic leadership is above their own ego and encourages women to take on roles and risks they would not otherwise, but it only helps them to be even more resilient after overcoming challenges (Evelyn, 2015). With greater authenticity, thanks to self-awareness, women leaders accept new opportunities to become the best in their work and environment and to dedicate their full abilities to management in the organization. Authentic leadership is associated with actions for the collective rather 
than the pursuit of the leader's self-interest (Steffens et al., 2016). Increasing leadership potential and influence in organizations in which women operate is possible through authenticity, rather than adopting and adapting characteristics based on other people's expectations (Berkovich \& Gueta, 2020).

Authentic women leaders are not only aware of their knowledge, values, morals, and strengths, but they consciously apply them as the preferred leadership style in this case the authentic style (Avolio et al., 2007). Authentic women leaders are honest in their actions, present themselves as individuals confident in themselves and their abilities, use heart and mind in business, and are available to their co-workers and employees (Irvine \& Reger, 2006). The ability of a women leader to be empathetic and compassionate had the greatest correlation to profitability and productivity. They instill trust and have true followers (Silva, 2014). Authentic women leaders seek to gain feedback through interactions with others (Neider \& Schriesheim, 2011) For this reason, it is necessary to further explore authentic women leaders and their characteristics (Brown, 2018).

\section{Method}

In the research of female authentic leadership 113 women leaders participated. A structured questionnaire was used and distributed during November and December 2020 to 150 addresses (via e-mail or social networks). The survey completion rate is $75.33 \%$. The questionnaire contained two types of questions, demographic and questions related to authentic leadership. Demographic issues related to education, age structure, and type of activity in which women leaders operate and the number of years of work experience in the designated activity. The second part of the questionnaire contained 16 closed-ended questions. The questions were translated into Serbian and adapted to the research, and the basis for the questionnaire is the Authentic Leadership Self-Assessment Questionnaire constructed by Northouse (2018). The questionnaire is divided into 4 parts, each part denoting one of the characteristics of authentic leaders: self-awareness $(1,5,9,13)$, internalized moral perspective $(2,6,10,14)$, balanced information processing $(3,7,11,15)$ and relational transparency $(4,8,12,16)$. Respondents completed this part of the survey based on their own characteristics and their subjective interpretation. It was necessary for women to represent leaders in the activities they are engaged in and to hold middle and top management positions in the organizations in which they work.

\section{Results}

Descriptive analysis was used to present the results. The analysis of rresponses to the Authentic Leadership Self-Assessment Questionnaire was performed based on a codebook set by Northouse (2018). 
Table 1. Demographic structure of respondents

\begin{tabular}{lcc}
\hline & \multicolumn{2}{c}{ Frequency $(N=113)$} \\
\cline { 2 - 3 } Education & $N$ & $\%$ \\
High school & 21 & 18.6 \\
College & 32 & 28.3 \\
Bachelor's degree & 37 & 32.7 \\
Master's degree & 20 & 17.7 \\
PhD & 3 & 2.7 \\
Age & & \\
$18-25$ & 4 & 3.5 \\
$26-35$ & 42 & 37.2 \\
$36-45$ & 43 & 38.1 \\
$46-55$ & 19 & 16.8 \\
$56-65$ & 5 & 4.4 \\
Year of work experience & & \\
$0-2$ & 10 & 8.8 \\
$3-5$ & 24 & 21.2 \\
$5-10$ & 33 & 29.2 \\
$10-15$ & 31 & 27.4 \\
$15-20$ & 8 & 7.1 \\
Over 20 & 7 & 6.2 \\
Activity & & \\
Production & 24 & 21.2 \\
Services & 74 & 65.5 \\
Production \& Services & 15 & 13.3 \\
\hline
\end{tabular}

Source: Author's calculation based on SPSS 21.0

The second part of the questionnaire is designed to measure the authenticity of women leaders by assessing four dimensions of authentic leadership: self-awareness, internalized moral perspective, balanced information processing and relational transparency. By adding values according to the code for each of the 4 components, it is determined which are stronger and which are less pronounced characteristics in women leaders The results are interpreted on the basis of the following guidelines: high authenticity characterizes those women leaders whose sum according to individual characteristics exceeds 16 (range 16-20), and low authenticity characterizes those whose result is 15 and less (range 4-15). The results in the upper range show stronger authentic leadership, and in the lower range weaker authentic leadership.

Table 2. Authentic Leadership Characteristic

\begin{tabular}{cccccccc}
\hline \multicolumn{2}{c}{ Self-Awareness } & \multicolumn{2}{c}{\begin{tabular}{c} 
Internalized Moral \\
\multicolumn{2}{c}{ Perspective }
\end{tabular}} & \multicolumn{2}{c}{$\begin{array}{c}\text { Balanced } \\
\text { Processing }\end{array}$} & \multicolumn{2}{c}{$\begin{array}{c}\text { Relational } \\
\text { Transparency }\end{array}$} \\
\hline 1 & 4.06 & 2 & 3.86 & 3 & 3.77 & 4 & 3.85 \\
5 & 3.96 & 6 & 3.90 & 7 & 3.78 & 8 & 3.82 \\
9 & 3.78 & 10 & 3.88 & 11 & 3.78 & 12 & 3.96 \\
13 & 3.86 & 14 & 3.94 & 15 & 3.75 & 16 & 3.72 \\
\multicolumn{2}{c}{15.66} & \multicolumn{2}{c}{15.58} & \multicolumn{2}{c}{15.08} & \multicolumn{2}{c}{15.35} \\
\hline
\end{tabular}

Source: Author's calculation based on SPSS 21.0 
Based on the answers of all 113 respondents, it is concluded that none of the characteristics is extremely evident, although self-awareness is close to the limit. The least manifest feature is the balanced processing of information. If individual results are considered, only 31 respondents have a sum in the individual characteristics of 16 and more. The most evident characteristic is self-awareness (17.58), while the least evident characteristic is transparency (17.16). Only three women leaders are seen to have strongly expressed characteristics of authentic leaders. The results show that selfawareness is the most evident characteristic (19.33), and transparency is the least evident characteristic (18).

The research was continued in the direction of examining the demographic characteristics described by women in whom a strong existence of the characteristics of authentic leaders was observed.

Table 3. Demographic structure of authentic women leaders

\begin{tabular}{lcc}
\hline & \multicolumn{2}{c}{ Frequency $(N=31)$} \\
\cline { 2 - 3 } Education & $N$ & $\%$ \\
High school & 8 & 25.8 \\
College & 6 & 19.3 \\
Bachelor's degree & 10 & 32.3 \\
Master's degree & 7 & 22.6 \\
PhD & - & - \\
Age & & \\
$18-25$ & 2 & 6.4 \\
$26-35$ & 8 & 25.8 \\
$36-45$ & 11 & 35.5 \\
$46-55$ & 8 & 25.8 \\
$56-65$ & 2 & 6.5 \\
Year of work experience & & \\
$0-2$ & 2 & 6.4 \\
$3-5$ & 6 & 19.4 \\
$5-10$ & 7 & 22.6 \\
$10-15$ & 8 & 25.8 \\
$15-20$ & 5 & 16.1 \\
Over 20 & 3 & 9.7 \\
Activity & & \\
Production & 6 & 19.4 \\
Services & 20 & 64.5 \\
Production \& Services & 5 & 16.1 \\
\hline$\quad$ Source: Authors & & \\
\hline
\end{tabular}

Source: Author's calculation based on SPSS 20.0

Among women leaders who have been shown to possess all four characteristics of authentic leaders, in most cases they have a university degree, aged 36-45, are engaged in services and have radon experience of 10-15 years in the business in which they are engaged.

In three schemes that were shown to have distinct characteristics of authentic leadership, the results show that all three are engaged in services, have a university 
degree, between 26-35 years and have an average of 10 years of work experience in the activities in which they are engaged.

\section{Discussion}

Leadership abilities depend on personal strength and certain qualities and should not be related to gender. In Serbia, women are usually not encouraged enough and rarely take leadership positions. Women in Serbia are as qualified as men to lead and be part of the organization's top management. Today, women leaders in Serbia use strategies that help people fit together, they create connection, consistency and credibility, they build trust, achieve results and strengthen the organization and employees.

Women leaders view work as an integral part of their lives that is connected and intertwined with other elements (Klanke, 2017). Self-awareness is important for authentic women leaders and the following factors are crucial for them: meaning, purpose, motivation, connection with colleagues and the balance between business and private life (Gipson et al., 2017). In this research, self-awareness is a characteristic that is most prevalent in authentic women leaders in Serbia. Also, women leaders share their knowledge, help the team and the organization to progress and they are connected with employees.

Women authentic leaders in Serbia value relationships with others, they understand what motivates others and know how to recognize the quality of employees based on their engagement. Women leaders in Serbia know when to take the time to listen to someone, instead of rushing through decisions. Women-authentic leaders give a chance to others to explain, they know how to respect employees, even when they disagree with them (Gardiner, 2015).

Women leaders are caring by nature and therefore always ready to help employees develop and thrive. Women are enthusiastic and passionate, which is why they can make bold, but wise decisions. They rely on their team and create a friendly work environment full of cooperation (Giallonardo et al., 2010). They are determined and react quickly so that they can solve more problems and tasks at the same time, which is necessary for good authentic leadership.

Women leaders in Serbia solve problems creatively and know how to respond to challenges. Communication is a skill that is most often attributed to women, and those who are in leadership positions know how to use it, whether it is communication with employees, colleagues, clients, partners (Halim \& Razak, 2014). Women leaders in Serbia communicate openly, regularly and clearly, but this research shows that transparency is the least evident characteristic of authentic leaders in Serbia.

Women in Serbia are great leaders, they are imaginative, have great ideas and know how to inspire a team, and most importantly, they know how to turn dreams into deeds and concrete results. Authentic women leaders know how to put their ego aside, which is why they do business more thoughtfully and make better decisions (Ford \& Harding, 2011). Women leaders in Serbia like to turn the impossible into the possible and most often do not allow others to notice their difficulties. They are pragmatic, resilient and 
graceful and their perspective is different. That is why women are great leaders, they fight for their position and fight for their place at the top (Hannah et al., 2011).

\section{Conclusions}

Women leaders in Serbia have excellent predispositions to be authentic leaders. They are characterized by self-awareness, internalized moral perpective and relational transparency in relations with employees. Authentic women leaders, regardless of the gap that exists in Serbia between women leaders and men leadres, show that with their knowledge, behavior, attitudes, way of thinking and managing others, women leaders deserve the positions they hold. Authentic women leaders re-examine themselves and their actions, carefully choose how they will act, make the organization's business more democratic and inclusive with all those who work there, are more willing to seek help, avoid mistakes, are not afraid to put the organization's needs ahead of their ego. Authentic women leaders encourage themselves and their employees to achieve the goals of the organization, but beyond that, they encourage employees to continuous improvement and advancement. They are ready to accept other people's opinion, different from theirs, but also criticism and remarks on their own decisions.

This research has certain limitations. Primarily, the territorial distribution of the questionnaire in future research may be limited to a specific region (Raški, Rasinski, Sumadija...). A small number of respondents may not show heterogeneity in the characteristics of women leaders. The activities that women leaders do are divided into three categories in the questionnaire (production, services and production $\&$ services), there is a possibility to strictly define the activities, in terms of specifying the specific work that women leaders do (banks, pharmacies, cosmetics, travel agencies, furniture, programming, language school, hospitality, bakery...).

The biggest limitation of the work is reflected in the fact that the questionnaire used was related to the self-assessment of the women leaders about personal characteristics. From a conceptual standpoint, authentic leadership is not the same as feeling authentic. Whether a person feels authentic is fundamentally different from them being perceived as authentic by others. Both felt and perceived authenticity are subjective and perceptual in nature, yet, the former is self-referential and the latter refers to others 'views of the target individual (Randolph-Seng \& Gardner, 2013). Being seen as authentic by others, specifically by one's followers, lies at the heart of the currently best-established conceptualization of authentic leadership (Gardner et al., 2011). Future research should also include employees so that they can provide answers how authentic their leaders are. So perform a comparative analysis of the responses of women leaders and their employees and assess how much women leaders are aware of themselves and personality characteristics.

There is a possibility of adding more variables, in order to assess the impact of women authentic leadership on employee motivation, job commitment, job satisfaction, etc. 


\section{References}

Algera, P. M., \& Lips-Wiersma, M. (2012). Radical authentic leadership: Co-creating the conditions under which all members of the organization can be authentic. The Leadership Qquarterly, 23(1), 118-131. https://doi.org/10.1016/j.leaqua.2011.11.010

Alilyyani, B., Wong, C. A., \& Cummings, G. (2018). Antecedents, mediators, and outcomes of authentic leadership in healthcare: A systematic review. International Journal of Nursing Studies, 83, 34-64. https://doi.org/10.1016/j.ijnurstu.2018.04.001

Avolio, B. J. (2011). Full range leadership development. Sage Publications.

Avolio, B. J., \& Gardner, W. L. (2005). Authentic leadership development: Getting to the root of positive forms of leadership. The Leadership Quarterly, 16(3), 315338. https://doi.org/10.1016/j.leaqua.2005.03.001

Berkovich, I., \& Gueta, B. (2020). Teachers' authentic leadership and psychological need satisfaction climate in second chance programmes: The moderating role of teachers' gender. Educational Management Administration \& Leadership, 1741143220957340. https://doi.org/10.1177\%2F1741143220957340

Bligh, M. C., \& Kohles, J. C. (2008). Negotiating gender role expectations: Rhetorical leadership and women in the US Senate. Leadership, 4(4), 381-402. https://doi.org/10.1177\%2F1742715008095187

Brown, B. (2018). Dare to Lead: Brave Work. Tough Conversations. Whole Hearts. Random House.

Dramićanin, S. (2019). The impact of authentic leadership on the commitment of employees in travel agencies in the Republic of Serbia. BizInfo (Blace) Journal of Economics, Management and Informatics, 10(1), 29-41. https://doi.org/10.5937/bizinfo1901029D

Evelyn, J. (2015(. Best Practice Series: Women in Leadership. Korn Ferry Institute.

Gardiner, R. (2016). Gender, authenticity and leadership: Thinking with Arendt. Leadership, 12(5),

632-637. https://doi.org/10.1177\%2F1742715015583623

Gardner, W. L., Cogliser, C. C., Davis, K. M., \& Dickens, M. P. (2011). Authentic leadership: A review of the literature and research agenda. The Leadership Quarterly, 22(6), 1120-1145. https://doi.org/10.1016/j.leaqua.2011.09.007

Gardner, W. L., Avolio, B. J., Luthans, F., May, D. R., \& Walumbwa, F. (2005). “Can you see the real me?" A self-based model of authentic leader and follower development. The Leadership Quarterly, 16(3), 343-372. https://doi.org/10.1016/j.leaqua.2005.03.003

George, B. (2003). Authentic leadership: Rediscovering the secrets to creating lasting value. John Wiley \& Sons.

Giallonardo, L. M., Wong, C. A., \& Iwasiw, C. L. (2010). Authentic leadership of preceptors: predictor of new graduate nurses' work engagement and job satisfaction. Journal of Nursing Management, 18(8), 993-1003. https://doi.org/10.1111/j.1365-2834.2010.01126.x

Gipson, A. N., Pfaff, D. L., Mendelsohn, D. B., Catenacci, L. T., \& Burke, W. W. (2017). Women and leadership: Selection, development, leadership style, and performance. The Journal of Applied Behavioral Science, 53(1), 32-65. https://doi.org/10.1177\%2F0021886316687247 
Halim, N. A. A., \& Razak, N. A. (2014). Communication strategies of women leaders in entrepreneurship. Procedia-Social and Behavioral Sciences, 118, 21-28. https://doi.org/10.1016/j.sbspro.2014.02.003

Hannah, S. T., Walumbwa, F. O., \& Fry, L. W. (2011). Leadership in action teams: Team leader and members' authenticity, authenticity strength, and team outcomes. Personnel Psychology, 64(3), 771-802. https://doi.org/10.1111/j.1744-6570.2011.01225.x

Heilman, M. E. (2012). Gender stereotypes and workplace bias. Research in organizational Behavior, 32, 113-135. https://doi.org/10.1016/j.riob.2012.11.003

Hopkins, M. M., \& O’Neil, D. A. (2015). Authentic leadership: Application to women $\begin{array}{lll}\text { leaders. Frontiers in Psychology, 6, } & 959 .\end{array}$ https://doi.org/10.3389/fpsyg.2015.00959

Ibarra, H. (2015). The authenticity paradox. Harvard Business Review, 93(1/2), 5359.

Ilies, R., Morgeson, F. P., \& Nahrgang, J. D. (2005). Authentic leadership and eudaemonic well-being: Understanding leader-follower outcomes. The Leadership Quarterly, 16(3), 373-394. https://doi.org/10.1016/j.leaqua.2005.03.002

Iqbal, S., Farid, T., Khan, M. K., Zhang, Q., Khattak, A., \& Ma, J. (2020). Bridging the Gap between Authentic Leadership and Employees Communal Relationships through Trust. International Journal of Environmental Research and Public Health, 17(1), 250. https://doi.org/10.3390/ijerph17010250

Irvane, D., \& Reger, J. (2006). The Authentic Leader: It's About Presence, Not Position. Midpoint Trade Books.

Klenke, K. (Ed.). (2017). Women in leadership: Contextual dynamics and boundaries. Emerald Group Publishing.

Leroy, H., Anseel, F., Gardner, W. L., \& Sels, L. (2015). Authentic leadership, authentic followership, basic need satisfaction, and work role performance: A cross-level study. Journal of Management,41(6), 1677-1697. https://doi.org/10.1177\%2F0149206312457822

Liu, H., Cutcher, L., \& Grant, D. (2015). Doing authenticity: The gendered construction of authentic leadership. Gender, Work \& Organization, 22(3), 237-255. https://doi.org/10.1111/gwao.12073

Luthans, F., \& Avolio, B., (2003). Authentic leadership: a positive development approach. In Cameron, K. S., Dutton, J. E., Quinn, R. E. (Eds.). Positive Organizational Scholarship (pp. 241-258) .Berrett-Koehler.

Neider, L. L., \& Schriesheim, C. A. (2011). The authentic leadership inventory (ALI): Development and empirical tests. The Leadership Quarterly, 22(6), 1146-1164. https://doi.org/10.1016/j.leaqua.2011.09.008

Northouse, P. G. (2018). Leadership: Theory and practice. Sage publications.

Qiu, S., Alizadeh, A., Dooley, L. M., \& Zhang, R. (2019). The effects of authentic leadership on trust in leaders, organizational citizenship behavior, and service quality in the Chinese hospitality industry. Journal of Hospitality and Tourism Management, 40, 77-87. https://doi.org/10.1016/j.jhtm.2019.06.004

Randolph-Seng, B., \& Gardner, W. L. (2013). Validating measures of leader authenticity: Relationships between implicit/explicit self-esteem, situational 
cues, and leader authenticity. Journal of Leadership \& Organizational Studies, 20(2), 214-231. https://doi.org/10.1016/j.jhtm.2019.06.004

Shen, H., \& Kim, J. N. (2012). The authentic enterprise: Another buzz word, or a true driver of quality relationships?. Journal of Public Relations Research, 24(4), 371-389. https://doi.org/10.1080/1062726X.2012.690255

Silva, A. (2014). What do we really know about leadership?. Journal of Business Studies Quarterly,5(4), 1-4.

Steffens, N. K., Mols, F., Haslam, S. A., \& Okimoto, T. G. (2016). True to what we stand for: Championing collective interests as a path to authentic leadership. The Leadership Quarterly, 27(5), 726-744. https://doi.org/10.1016/j.leaqua.2016.04.004

Udani, Z. A. S., \& Lorenzo-Molo, C. F. (2013). When servant becomes leader: The Corazon C. Aquino success story as a beacon for business leaders. Journal of Business Ethics, 116(2), 373-391. https://doi.org/10.1007/s10551-012-1449-5

Walumbwa, F. O., Avolio, B. J., Gardner, W. L., Wernsing, T. S., \& Peterson, S. J. (2008). Authentic leadership: Development and validation of a theory-based measure. Journal of Management, 34(1), 89-126. https://doi.org/10.1177\%2F0149206307308913

Walumbwa, F. O., Wang, P., Wang, H., Schaubroeck, J., \& Avolio, B. J. (2010). Psychological processes linking authentic leadership to follower behaviors. The Leadership Quarterly, 21(5), 901-914.

Zander, L. (2013). Viewpoint: An authentic jerk. Authentic leadership can be bad leadership. In Ladkin, D., Spiller, C. (Eds.), Authentic leadership: Clashes, convergences and coalescences (pp.279-281). Cheltenham: Edward Elgar.

Appendix 1. Questionnaire

\begin{tabular}{cr}
\hline 1 & I can list my three greatest weaknesses. \\
2 & My actions reflect my core value. \\
3 & I seek others' opinions before making up my own mind. \\
4 & I openly share my feelings with others. \\
5 & I can list my three greatest strengths. \\
6 & I do not allow group pressure to control me. \\
7 & I listen closely to the ideas of those who disagree with me. \\
8 & I lethers know who I truly am as a person. \\
9 & I seek feedback as a way of understanding who I really am as a person. \\
10 & Other people know where I stand on controversial issues. \\
11 & I do not emphasize my own point of view at the expense of others. \\
12 & I rarely present a "false" front to others. \\
13 & I accept the feelings I have about myself. \\
14 & My morals guide what I do as a leader. \\
15 & I listen very carefully to the ideas of others before making decisions. \\
16 & I admit my mistakes to others. \\
\hline
\end{tabular}

Source: Northouse, P. G. (2018). Leadership: Theory and practice. Sage publications. 
Scoring:

1. Self-awareness: $1,5,9,13$

2. Internalized Moral Perspective 2, 6, 10, 14

3. Balanced Processing 3, 7, 11, 15

4. Relational Transparency 4, 8, 12, 16

Rad je primljen: 17.11.2020; Prihvaćen: 18.12.2020.

Received: 17 November, 2020; Accepted: 18 December, 2020 
